\title{
Multivariable Control of a Binary Distillation Column
}

\section{José Leonardo Benavides Maldonado, Jorge Michael Valarezo, Darwin Tapia Peralta}

\begin{abstract}
University National of Loja in the southern Ecuador and associated people with the oil industry. Two strategies to control some parameters of a binary distillation tower, such as LQR (Linear Quadratic Regulator) and another in intelligent control such as fuzzy logic controllers

With purpose of comparison with the help of MATLAB ${ }^{\circledR}$ software and Simulink ${ }^{\circledR}$ the benefits offered by the use of either strategy in the oil industry.
\end{abstract}

Index Terms- Chemical Industry, Distillation Columns, Fuzzy Control, LQR Control.

\section{INTRODUCTION}

This The need for professionals who can work in the oil industry, is growing in Ecuador so it is important that students of the National University of Loja will relate more to this process in their academic training so one of the objectives of this paper is intended to raise awareness of this process.

An application to understand this process is a simple classical binary distillation tower where unlike those used in the oil industry is responsible for separating a liquid mixture of two substances with different degrees of volatility document is a template. An electronic copy can downloaded from the conference website. For questions on paper guidelines, please contact the conference publications committee as indicated on the conference website. Information about final paper submission is available from the conference website.

This achieved because a distillation tower is a system for continuous reheating reheated at the bottom [1]. This shown more detail in Fig. 1. Where it shows a distillation column in which a flow $\mathrm{F}$ with $\mathrm{Zi}$ composition is fed, a distillate $\mathrm{D}$ in the top you will have an $\mathrm{Xd}$ composition and $\mathrm{B}$ flow with $\mathrm{Xb}$ composition also can be seen a reflux $\mathrm{L}$.

This will always exist for a more adequate purification, this reflux is the part that is condensed and the other is the part that comes out as a finished product this part of the tower.

Known as rectification zone here increases the more volatile component, while at the bottom the heaviest component increases and thus reduces the lighter component [2].

Can also see in this same figure on the right a reflux drum where the condensate temporarily stored, to distill and a pump to evacuate the above [3].

Manuscript received December 13, 2015.

José L. Benavides M, Electromechanical, University National of Loja, Loja, Ecuador, 0959167589, (e-mail: j.benavides@unl.edu.ec).

Jorge Michael Valarezo, Geology and mines, University National of Loja, Loja, Ecuador, 0987679808, (e-mail: j.valarezo@unl.edu.ec).

Darwin Tapia Peralta, Electromechanical, Loja, Ecuador, 0988879915, (e-mail: d.tapia@unl.edu.ec).

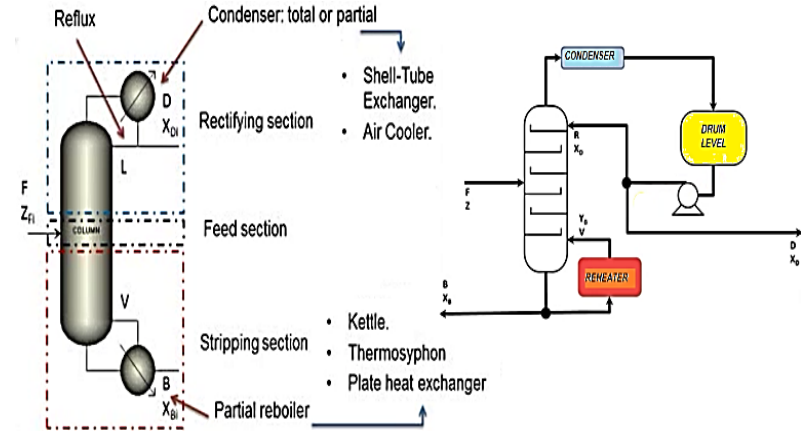

Fig. 1 In the left figure the stages shown operating of a binary distillation tower and in the right of this figure a distillation tower with a drum to control the level of reflux. Source photograph: left http://www.youtube.com/watch?v=jeCZ4UKfLKc, right http://www.youtube.com/watch?v=sYIkyDQVTzA\&list=PL995A30D4624 $\underline{4 \mathrm{C} 35 \mathrm{~B}}$

\section{MATERIALS AND METHODS}

For nonlinear systems there are a large variety of structures and techniques such as, neural networks, support vector machines least squares (LVS-SVMs), fuzzy logic [4]. Two of these strategies have elected to meet certain parameters of the distillation tower.

\subsection{Definition of state space}

The idea comes from paper the state-space method for describing in state variable differential equations. Here the dynamical systems described by a set of differential equations of first order in known state variables and the solution can considered as a solution in the state trajectory. This method is ideal to perform calculations with the help of a computer. The design of state-space control is a technique by which the control engineer designs the compensation directly using the description of the system state variables.

Also called modern control design, while methods based on transfer function, as the locus of the roots and the frequency response called classical control design, but their release date is a mistake to refer as modern, and it is preferable to refer to the two as an approach to the design and methods of state space method [5].

The stable models are described by two equations the state equation which is shown by one, two.

$$
\begin{aligned}
& \dot{X}=A x+B u \\
& y=C x+D u
\end{aligned}
$$

Where $\mathrm{Y}(\mathrm{t})$ represents the output of the system, $\mathrm{x}(\mathrm{t})$ is the system state, $\mathrm{u}(\mathrm{t})=$ the system input and $\mathrm{X}$ is the future state of the system depending on the current state and of the output of the input of the system [6]. 


\subsection{Linear Quadratic Regulator (LQR)}

Assuming all the system state can measured, we know possible to design a state feedback control that minimizes the value of a quadratic cost functional infinite horizon defined by three.

$$
J:=\int_{0}^{\infty}\left(X^{T} Q x+\epsilon^{-1} u^{T} u\right) d t
$$

Where $\mathrm{Q}$ is a positive matrix and is a positive constant, the control law shown in equation four.

$$
\text { u._opt }=-r^{-1} B^{T} P x
$$

Where $\mathrm{P}$ is positive definitive matrix as a solution to the algebraic Riccati equation (ARE) with equation five.

$$
A^{T} P+P A-\in P B B^{T} P-Q=0
$$

That can be proved to exist as soon as A, B is a stabilizable pair, the firsts and seconds terms correspond to the energy of the controlled output and control signal, respectively, and the LQR strategy is to minimize, however, the decrease of a requires of both. The paper is to establish a dot between these behaviors in the conflict that given by the value of e [7].

\subsection{Fuzzy logic-based controllers}

Fuzzy logic aims to give a greater range of options when finding a solution to a particular problem but the solution given to a problem does not always allow a greater horizon of probabilities,

Zadeh proposed this problem the resolver by applying the logic of Lukasiewicz to find a solution designating each object in a set and I think a complete algebra for fuzzy sets.

This theory proposed membership functions $(\mu)$, or false and true values over the range $[0.0,1.0]$, the fuzzy degrees are not the same as the odds, these measure indicate something will happen or not, while fuzzy measure levels are a condition, i.e. has to be given a degree of belonging to the elements. The second step is to propose linguistic rules (inference), the degree of membership of each of the variables is evaluated on a set of inference rules. These were determined with the help of an expert. The inference rule set determines a consequence, that is, assigned a degree of membership of each fuzzy set, which characterizes the output.

After obtaining the consequences, the third stage is a process to determine the optimal values of output, known as defuzzification,

Which involves passing the grade of membership, from the result of the inference rule to a crisp or actual value to do this, previous membership functions of each of the outputs tuned in order to obtain a measurable value [8].

\subsection{Description of the process}

The problem describes a realistic problem of a binary distillation column, and has the feature that pressure variation is included in the model's description: the system is multivariable, with three inputs and three outputs, and includes one disturbance input; this presented in Fig. 2.

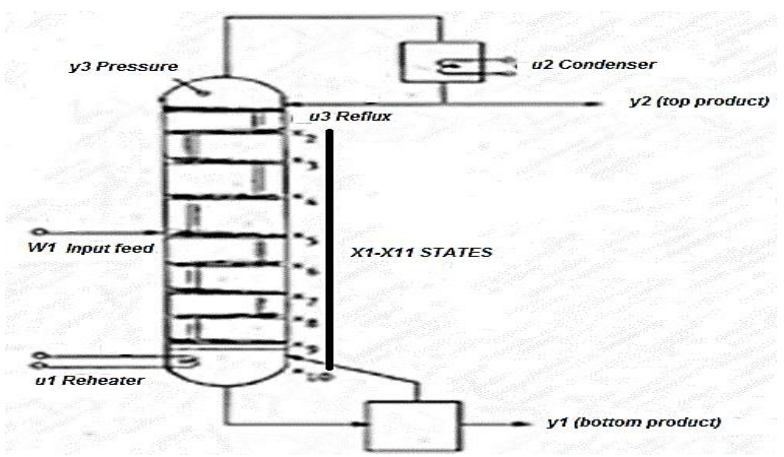

Fig. 2 Binary distillation column with pressure variation

The equation of binary distillation column with $\mathrm{n}$ plates for a general binary system of components given in the above reference six, seven, eight. This following linearized model obtained from the above reference, for a column containing eight plates

$$
\begin{gathered}
\dot{X}=A x+B u+E w \\
y=C x \\
y m=x
\end{gathered}
$$

Where $\mathrm{u}$, is the input:

$\mathrm{u}=\mathrm{u} 1, \mathrm{u} 2, \mathrm{u} 3, \quad(\mathrm{u} 1=$ Reboiler steam temperatura; $\mathrm{u} 2=$ Condenser coolant temperatura; $\mathrm{u} 3=$ Controlled reflux).

$\mathrm{Y}$ is the output:

$\mathrm{y}=\mathrm{y} 1, \mathrm{y} 2, \mathrm{y} 3,(\mathrm{y} 1=$ Composition of more volatile component in the bottom product; $y 2=$ Composition of more volatile component in top product; $\mathrm{y} 3=$ Pressure).

$\mathrm{X} 1=$ Composition of more volatile component in condenser $\mathrm{X} 10=$ Composition of more volatile component in reboiler

$\mathrm{X} 11=$ Pressure

$\mathrm{X} 2=$ Composition of more volatile component in the plate \#1

$\mathrm{X} 9=$ Composition of more volatile component in the plate \#8 $\mathrm{W} 1=$ Change of input feed concentration

It desired to design a controller to regulate three outputs y1, y2, y3 against the unmeasurable disturbance W1 and other unmeasurable disturbances, with as fact a settling time as possible, subject to the constraint.

$\left|u_{1}\right| \leq 2.5$

$\left|u_{2}\right| \leq 2.5 \quad t \geq 0$

$\left|u_{3}\right| \leq 0.30$

For $\mathrm{W} 1=1$ in this problem, the choice of what measurable outputs to use in the controller, is considered to be part of the problem statement; in general, a controller which uses the fewest number of output measurements is desirable [9].

\subsection{Process variables}

The process under study is a distillation tower whose variables are; Temperature, Pressure, Level and Flow, variables involved in the analysis are input (u1, u2, u3).

Which are replaced by the following abbreviations (Tf, Tr, $\mathrm{Re})$ and output (y1, y2, y3) which are replaced by the following abbreviations for greater understanding $\left(\mathrm{Cf}, \mathrm{Ct}_{\mathrm{o}}\right.$, $\mathrm{Pt}$ ), which can be seen in Table 1 . 
Table 1: Process Variables

\begin{tabular}{|c|c|}
\hline \multicolumn{2}{|c|}{ MODELO DE LA PLANTA } \\
\hline Input variables & Output variables \\
\hline $\begin{array}{l}\text { Reboiler steam temperature ( } \mathrm{Tf} \\
\text { ) }\left[{ }^{\circ} \mathrm{C}\right]\end{array}$ & $\begin{array}{l}\text { Composition of more volatile } \\
\text { component in the bottom product } \\
(C f)[\mathrm{g} / \mathrm{ml} \times 100=\% \text {, or mole } \\
\text { fraction is dimensionless] }\end{array}$ \\
\hline $\begin{array}{l}\text { Condenser coolant temperature ( } \\
\operatorname{Tr})\left[{ }^{\circ} \mathrm{C}\right]\end{array}$ & $\begin{array}{l}\text { Composition of more volatile } \\
\text { component in top product } \\
\text { ( Cto ) }[\mathrm{g} / \mathrm{ml} \times 100=\% \text {, or mole } \\
\text { fraction is dimensionless] }\end{array}$ \\
\hline Controlled reflux $(\mathrm{Re})[\mathrm{g} / \mathrm{min}]$ & $\begin{array}{l}\text { Pressure in the top }(P t) \text { [ which is } \\
\text { the same or Pascal Pa] }\end{array}$ \\
\hline \multicolumn{2}{|l|}{ Disturbances } \\
\hline $\begin{array}{l}\text { Change of input feed } \\
\text { concentration } \\
(W 1)[\mathrm{g} / \mathrm{min}] \\
\end{array}$ & \\
\hline
\end{tabular}

Then in in Fig. 3. The system variables represented in a black box model where it is clearly a model is MIMO or multivariable system with three inputs, three outputs and one disturbance that is food, the mixtures is alcohol and water.

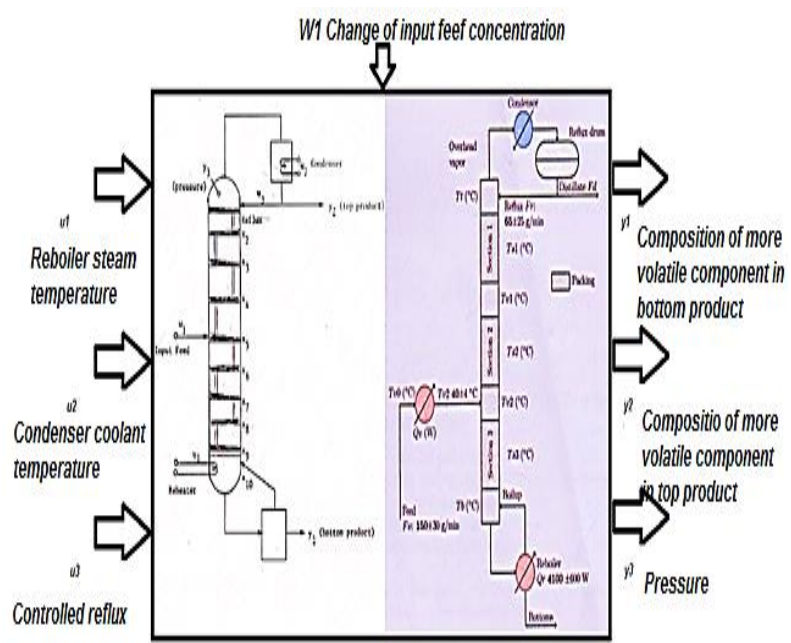

Fig. 3 Black box model of Binary distillation column, Source photograph: left [9], right [4]

When to wear this in state space system and simulate in Simulink, to understand the behavior of the outputs (Cf) (CTO), (Pt) to the inputs (Tf-2.5), (Tr-1.5), (Re-0.30) type step, is that the system is unstable as shown in Fig. 4.

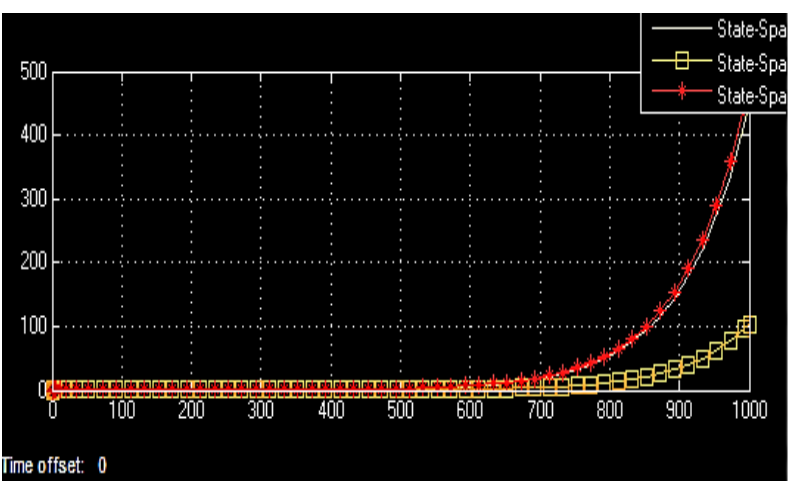

Fig. 4. Characteristics of the output of the Binary distillation column
To correct this unstable behavior of the system shown in the figure above, should be developed a small program in the MATLAB ${ }^{\circledR}$ editor that allows to present this state-space representation to an equation transfer function obtained will be carried Simulink ${ }^{\circledR}$ to be controlled through the design of three fuzzy controllers and then is one of the objectives of this work.

\section{RESULTS AND DISCUSSION}

\subsection{Control based on $L Q R$}

Is carried out a program in MATLAB ${ }^{\circledR}$ editor, using the toolbox with predictive models that have, specifically the ss command to state space, Here 4 matrices of different order are defined (Matrix A, B, C, D, and a sampling period).

These regulators LQR they have a penalty of exit and entry by the $\mathrm{R}$ matrix, and outputs the matrix $\mathrm{u}$, and then a sequence of operations that must be performed comes,

Here it is observed that the polynomial of $\mathrm{Y}$ has a penalty $\mathrm{Q}$, and the polynomial of $\mathrm{u}$ has an $\mathrm{R}$ penalty and then this multiplied by $\mathrm{Q}$ and that is the function to be minimized when the minimum of this function is optimal [10], [11].

The Fig. 5. Gives the result of LQR strategy applied to the process, indicating that all three outputs converge to zero as expected except that $\mathrm{y} 3$ is minimal but the difference to zero is $6 e^{-4}$ [12] [13].

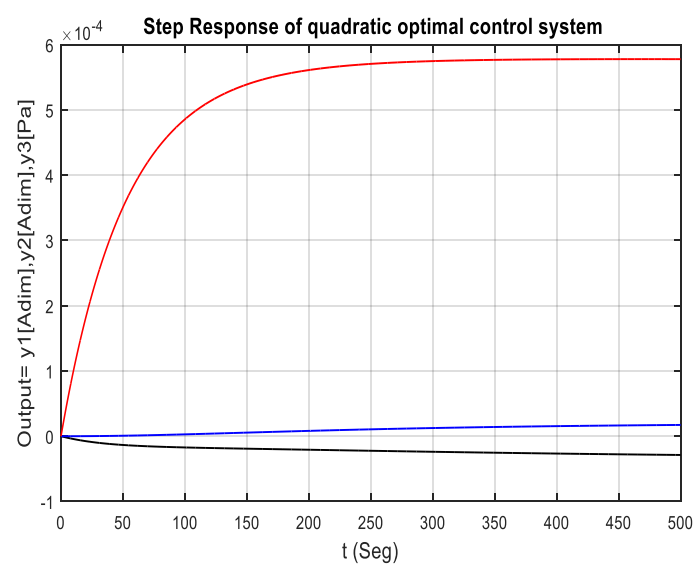

Fig. 5 Response to the three outputs of the system and as you can see is stable because all the answers emerge to zero

The response to the statements with a quadratic control strategy is almost zero; this can see in Fig. 6.

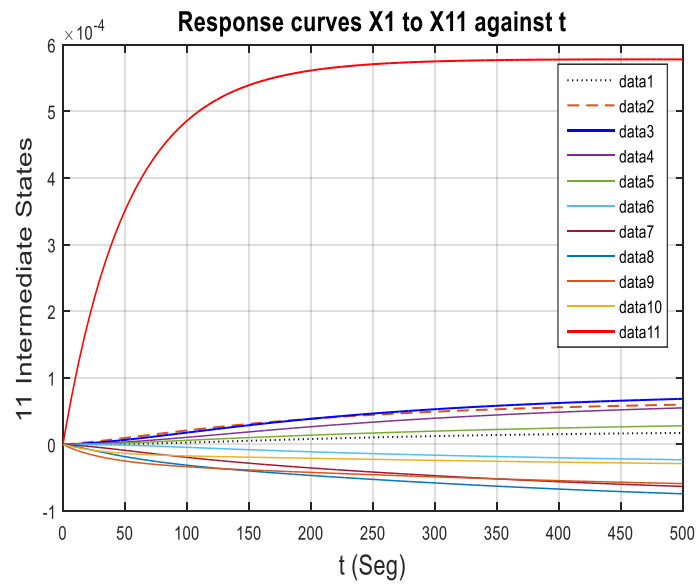

Fig. 6 Response of the 11 intermediate states when are use a LQR strategy of control 


\subsection{Control based on Fuzzy Logic}

For controller design Fuzzy must take into account some considerations in the distillation vapor in the process, such that the steam flow can considered constant throughout the column,

It is considered the evaporation process on each plate, overflow equimolar, which means that each molecule condenses delivery equal amount of energy which it absorbs a molecule liquid evaporates, thus the seam flow leaving the re-boiled, it is the same to the condenser, though with different concentrations through the variable control system shown in Fig. 7.

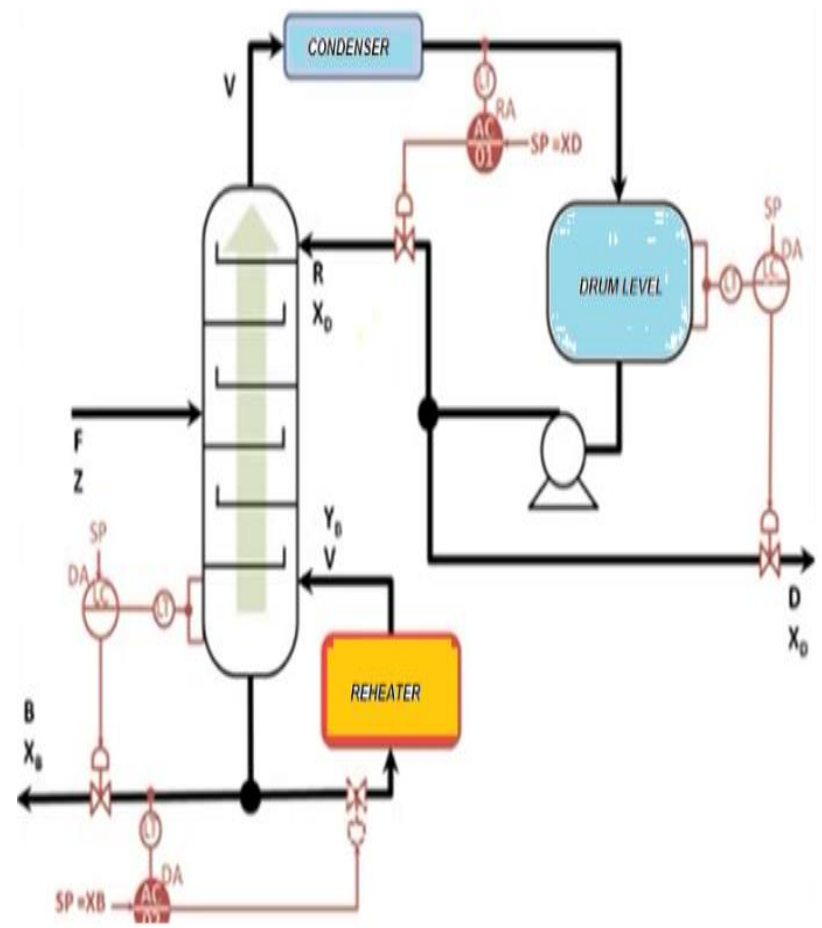

Fig. 7 Control scheme in where shown the sensors and actuators that must handle with the Fuzzy controller for output values desired. Photo Source:http://www.youtube.com/watch?v=sYIkyDQVTzA\&list=PL995A3 0D46244C35B

\subsubsection{Fuzzy Logic in MATLAB ${ }^{\circledR}$ and Simulink ${ }^{\circledR}$}

For the development of the rules of inference were used the criteria found in the previous tutorial [14], as well as data obtained from [4].

As mentioned above, the modeling has raised out using fuzzy logic techniques, due to their ability to model the human procedural knowledge and has been prepared by supporting the tool MATLAB ${ }^{\circledR}$. Work has done using a type of Mandani driver because it provides great advantages [15].

Then with the help of MATLAB ${ }^{\circledR}$ and your toolbox fuzzy you choose the functions membership and fuzzy rules are these can be seen in Table 2 .
Table 2: Fuzzy rules applied to variables input and output of the process.

\begin{tabular}{|c|c|c|c|c|c|}
\hline Variable & Label Language & Reflux(0-2.5) & $\begin{array}{l}\text { ConCooTem( } \\
0-2.5)\end{array}$ & $\begin{array}{l}\text { ReboSteam } \\
\text { Tem } \\
(0-0.30)\end{array}$ & $\begin{array}{l}\text { Input } \\
\text { Feed(0-1) }\end{array}$ \\
\hline $\begin{array}{c}\text { Comdes }(0 \\
-0.08)\end{array}$ & LITTLE & HIGH & LITTLE & HIGH & LITTLE \\
\cline { 2 - 6 } & HIGH & LITTLE & HIGH & LITTLE & HIGH \\
\hline $\begin{array}{c}\text { Comsed }(0 \\
-0.02\end{array}$ & HIGH & LITTLE & LITTLE & HIGH & LITTLE \\
\cline { 2 - 6 } & LITTLE & HIGH & HIGH & HIGH & HIGH \\
\hline \multirow{2}{*}{\begin{tabular}{c}
$\operatorname{Pre}(0-1)$ \\
\cline { 2 - 6 }
\end{tabular}} & HIGH & HIGH & LITTLE & HIGH & LITTLE \\
\cline { 2 - 6 } & LITTLE & LITTLE & HIGH & LITTLE & HIGH \\
\hline
\end{tabular}

In table 3 shows the results of the fuzzy rules of the process that must comply with the principle that the distillate is a very high concentration approximately 1 being the pure the most volatile element pure and the pellet has a concentration near shown so zero less volatile component.

Table 3: Simulated test for results

\begin{tabular}{|l|c|c|c|c|c|c|c|}
\hline $\begin{array}{l}\text { Variabl } \\
\mathrm{e}\end{array}$ & $\begin{array}{l}\text { Reflujo(0- } \\
2.5)\end{array}$ & $\begin{array}{l}\text { Temsalco } \\
\mathrm{n}(0-2.5)\end{array}$ & $\begin{array}{l}\text { Temreher } \\
(0-0.30)\end{array}$ & $\begin{array}{l}\text { Flujodeen } \\
(0-1)\end{array}$ & $\begin{array}{l}\text { Comdes(0 } \\
-0.8)\end{array}$ & $\begin{array}{l}\text { Coms } \\
\text { ed(0- } \\
0.02)\end{array}$ & $\begin{array}{l}\text { Pre(0- } \\
1)\end{array}$ \\
\hline $\begin{array}{l}\text { Comde } \\
\mathrm{s}(0-0.8)\end{array}$ & 0.43 & 2.02 & 0.0121 & 0.359 & 0.887 & & \\
\hline $\begin{array}{l}\text { Comse } \\
\mathrm{d}(0-0.0\end{array}$ & 0.161 & 0.193 & 0.242 & 0.0154 & & 0.015 & \\
2 & & & & & & 1 & \\
\hline $\begin{array}{l}\operatorname{Pre}(0-1 \\
\mathrm{P}(1)\end{array}$ & 1.9 & 0.1 & 0.27 & 0.1 & & & 0.792 \\
\hline $\begin{array}{l}P r e(0-1 \\
)\end{array}$ & 0.305 & 0.909 & 0.0158 & 0.959 & & & 0.163 \\
\hline
\end{tabular}

In Fig. 8 are shown the subsystem that was conducted to obtain the results of the figures $10,11 \mathrm{y} 12$.

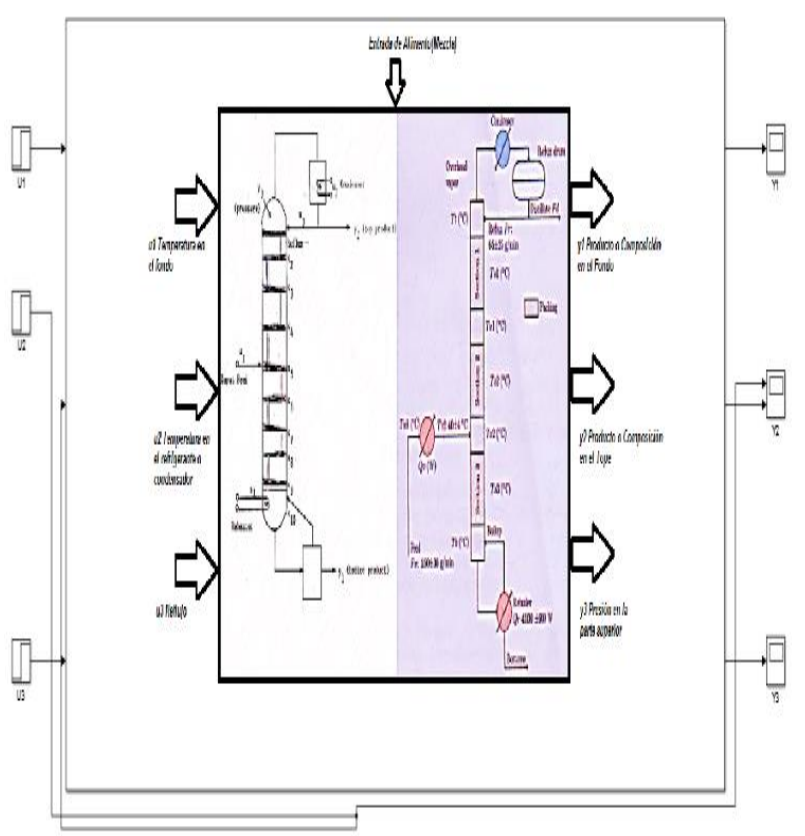

Fig. 8. Process represented as a subsystem, applying MATLAB ${ }^{\circledR}$

In the Fig. 9, the control development with the help of Simulik $^{\circledR}$ schown to control nine functions of transfer 


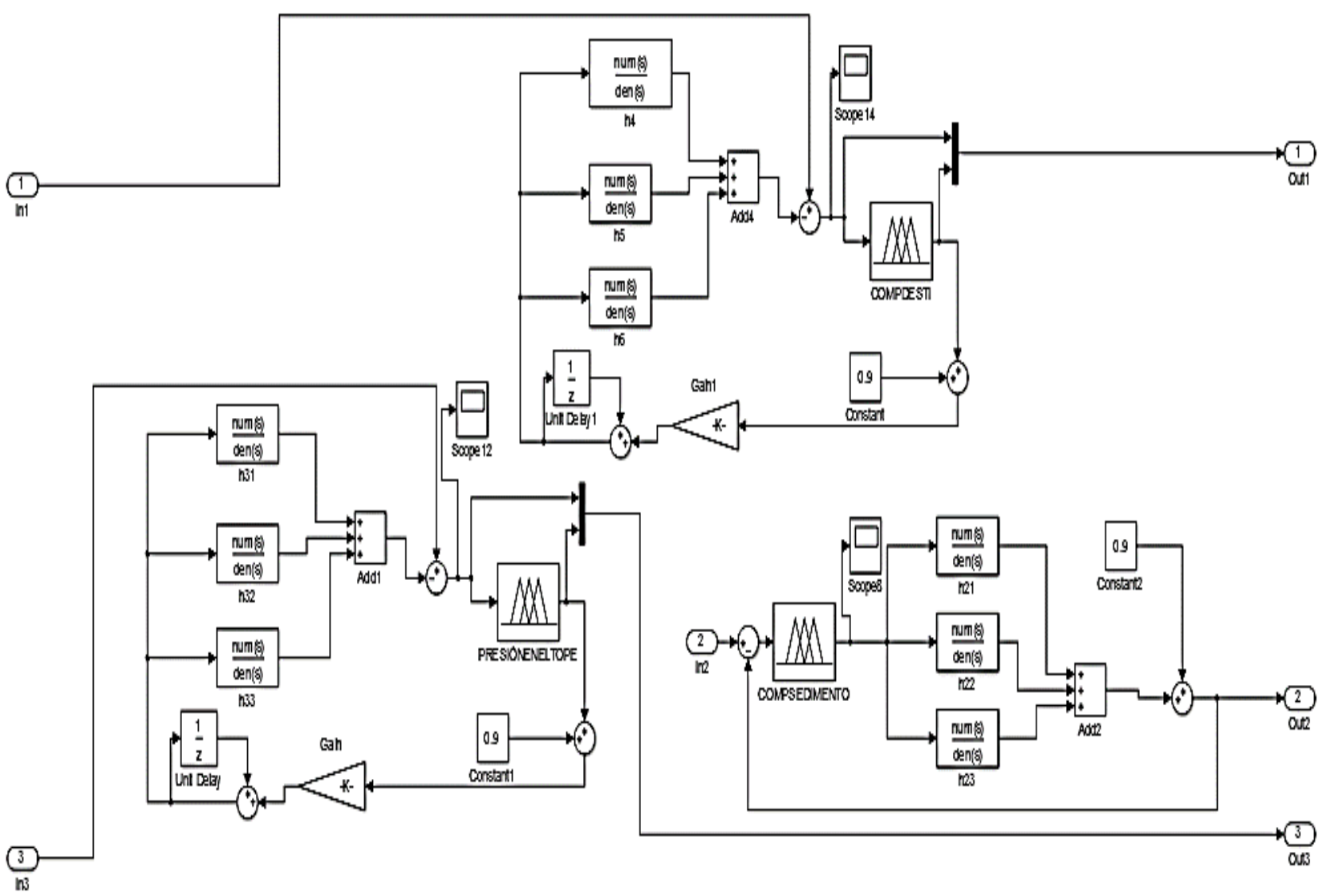

Fig. 9. Control Subsystem using Simulink ${ }^{\circledR}$

In the Fig. 10 shown the result the less volatile concentration the bottom sediment as close to zero, for this case would be the water

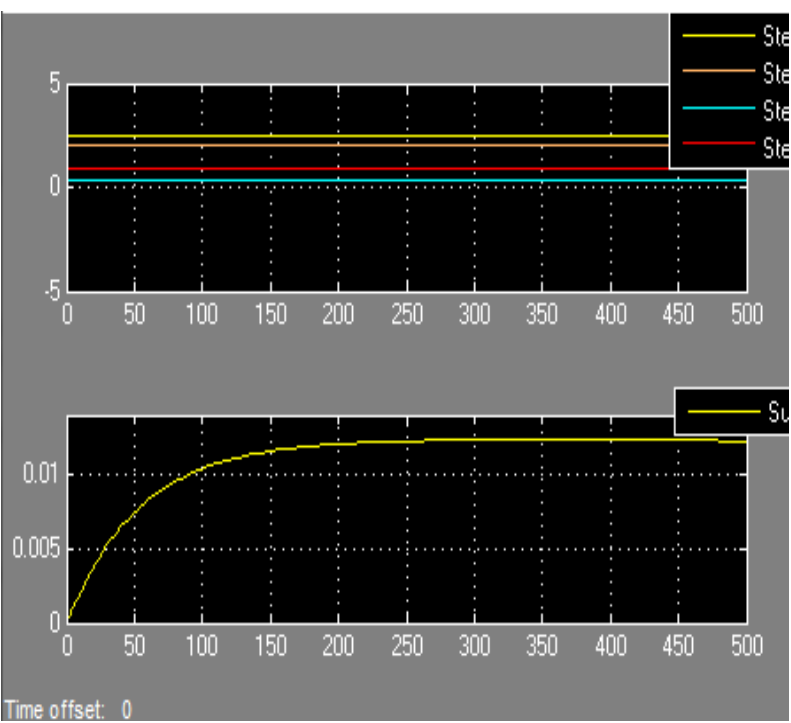

Fig. 10. Here is showing the concentration less volatile (water)

In the Fig. 11 shown the control result of the volatile composition in the top, the distillate is the concentration more volatile with a value close to one

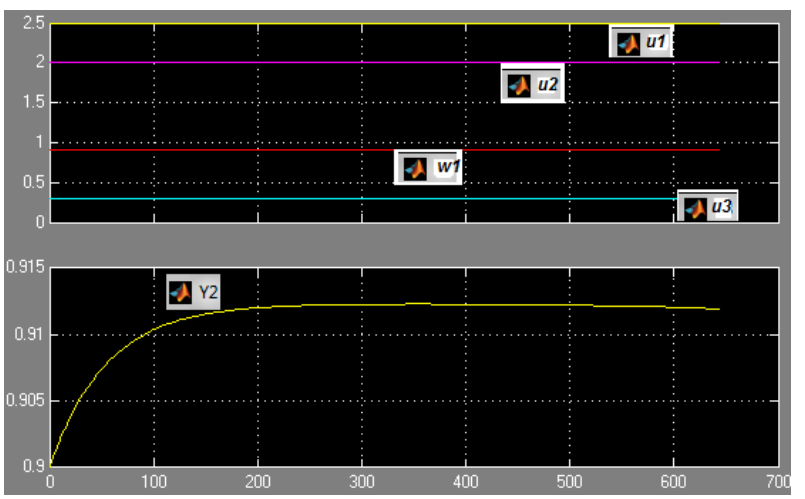

Fig. 11. Here is showing the concentration more volatile (alcohol),

In the Fig. 12 shown the result of pressure at the top of the column of distillation.

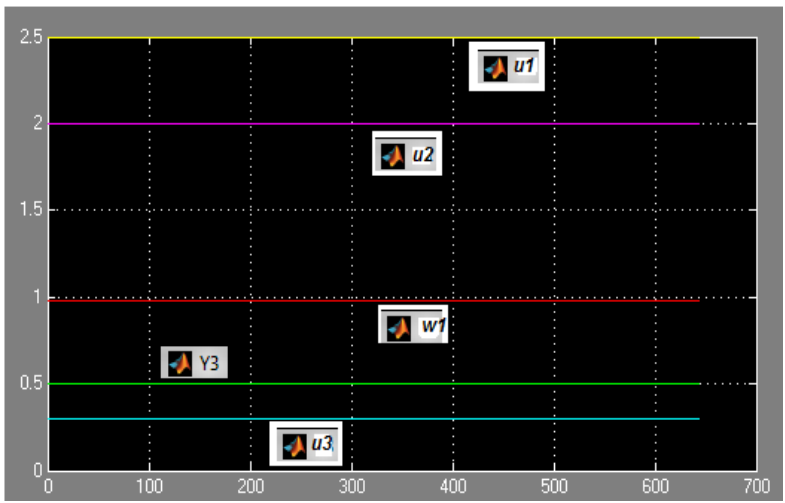

Fig. 12. Pressure in the top of distillation column binary 


\section{IV .CONCLUSION}

1. Are 9 transfer functions are obtained using state space the method because this process has three inputs and three outputs

2. The degree of the denominator is equal to the three transfer functions and represents the input state space or, as has 11 intermediate states $\mathrm{X}$ (is of the 11 order)

3. Because states are intermediate variables, combination $y$ $=\mathrm{Cx}+\mathrm{Du}$ is giving control outputs in this case are transfer functions (the nine) are shown in the subsystem of figure 8

4. The use of LQR strategy an allowed to converge to zero all the variables to control because it minimized to zero the square error (reference least output all squared).

5. The use of Fuzzy controller allows students of UNL had better understand the dynamics of distillation column.

6. Considering all the working conditions of the distillation column can assumed that the enthalpy between the dishes are equal.

7. Both methods are very effective in the control of the parameters of binary distillation tower but the potential of fuzzy method (fuzzy) allows better results in nonlinear processes (is presented as example the original model of the column. ).

8. The errors between the two Controllers the pressure is low in the LQR $(0,0005)$, while in ours fuzzy controllers is lower.

\section{REFERENCES}

[1] D. M. Fernández, Compositor, Torre de Destilación. [Grabación de sonido]. 2014.

[2] M. G. Macías, Escritor, Distillation and Absorption. [Performance]. 2011.

[3] A. Rojas, Escritor, Columna de destilación binaria - Parte 1. [Performance]. 2010.

[4] K. D. B. B. D. M. J. V. I. F. L. B. Huick, «Identification of a Pilot Scale Distillation Column: A Kernel Based Approach,» 18 th IFAC World Congress, 2 Septiembre 2011.

[5] J. D. P. A. E.-N. Gene F. Franklin, Control de Sistemas Dinámicos con Retroalimentación, Wilmington, Delaware : Addison-Wesley Iberoamerica, 1991, p. 310.

[6] S. Perez, Escritor, Modelos de Estado. [Performance]. 2014.

[7] J. F. G.-C. S. D. N. M. R. L. M. J.J. Téllez Guzmán, «Event-Based LQR Control for Attitude Stabilization of a Quadrotor,»XV Congreso Latinoamericano de Control Automático, 23 al 26 de Octubre Ocutbre 2012.

[8] P. P. Cruz, Intligencia Artificial con Aplicaciones a la Ingeniería, México: Alfaomega, 2010.

[9] E.J.Davison, Control of a distillation column with pressure variation, vol. 45, Toronto, Ontario: Trans Institute of Chemical Engineers, 1967, pp. 229-250.

[10] Mathworks, «Mathworks,» [En línea]. Available: www.mathworks.com.

[11] K. Ogata, Ingenieria de Control Moderno, Tercera ed., Prentice Hall, p. 933.

[12] S. P. o. m. a. J. Rawlings, "Constrained Linear Quadratic Regulations“, vol. 43, EEE Transactions on Automatic Control, 1998, pp. 1163-1169.

[13] J. a. D. Q. M. Rawlings, " Model Predictive Control Theory and Design", Nob Hill Publising, 2010.

[14] b. e. (. Hely Jurado Hurtado, Escritor, Columna de destilacion binaria. Obtenido de. [Performance]. 2010)..

[15] T. L. S. M. J. G. Z. Miguel Villeta, «Modelo para la Conducción Eficiente y Sostenible basado en Lógica Borrosa,» RIA (Revista Iberoamerica de Automática e Informática Industrial), vol. 9, $\mathrm{n}^{\circ} 3$ pp. 259-261-264, Julio/Septiembre 2012.

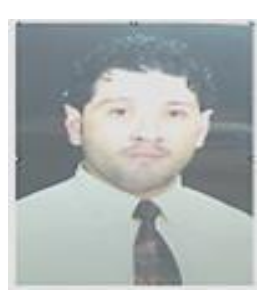

Leonardo Benavides received the title of Electromechanical engineering, from University National de Loja, Loja, Ecuador, in 2004, and Master in automatic and computer systems from Universidad Central Marta Abreu, Santa Clara, Cuba, 2008, and is a $\mathrm{PhD}$ student in Control Automatic in the ICIMAF, Habana Cuba. His current research interest are Virtual laboratories for teaching advanced control in mining copper and oil facilities in Ecuador.

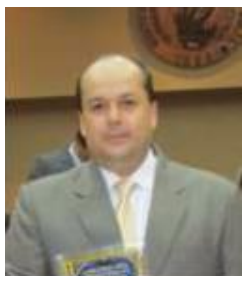

Michael Valarezo received the title mining engineering, at the University National of Loja, in the province of Loja Ecuador 1998, through interinstitucional agreement with the Institute Superior Metallurgical and mining of Cuba, has master degree in Environmental Management, Its interest in the field of research concerns the behavior of the practice and its involvements in Geotechnics and nature hazards.

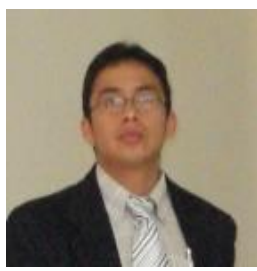

Darwin Tapia received the Engineering degree in Electromechanical from Universidad Nacional de Loja, Loja, Ecuador, in 2003, and Magister en Planificación y Gestión Energéticas receiver of Universidad de Cuenca, responsable del taller mecánico de la UNL, diseño CAD, CAE, CAM, maquinaría $\mathrm{CNC}$ 